\title{
Supplementation of prebiotics in infant formula
}

\author{
This article was published in the following Dove Press journal: \\ Nutrition and Dietary Supplements \\ 13 June 2014 \\ Number of times this article has been viewed
}

\section{Ana Močić Pavić Iva Hojsak}

Referral Center for Pediatric Gastroenterology and Nutrition, Children's Hospital Zagreb,

Zagreb, Croatia
Correspondence: Ana Močić Pavic Referral Center for Pediatric Gastroenterology and Nutrition, Children's Hospital Zagreb, Klaićeva I6, Croatia

Tel +385 I 4600 I30

Email amocicpavic@gmail.com
Background: In recent years prebiotics have been added to infant formula to make it resemble breast milk more closely and to promote growth and development of beneficial intestinal microbiota. This review aims to present new data on the possible positive effects of prebiotics in infant formula on intestinal microbiota (bifidogenic and lactogenic effect) and on clinical outcomes including growth, infections, and allergies. With that aim, a literature search of the Cochrane Central Register of Controlled Trials (CENTRAL), EMBASE, Scopus, PubMed/ Medline, Web of Science, and Science Direct in the last 10 years (December 2003 to December 2013) was performed.

Results: Altogether 24 relevant studies were identified. It was found that during intervention, prebiotics can elicit a bifidogenic and lactogenic effect. As far as clinical outcomes were concerned, 14 studies investigated the effect of infant formula supplemented with prebiotics on growth and found that there was no difference when compared with non-supplemented infant formula. All available data are insufficient to support prebiotic supplementation in order to reduce risk of allergies and infections.

Conclusion: There is currently no strong evidence to recommend routine supplementation of infant formulas with prebiotics. Further well-designed clinical studies with long-term follow-up are needed.

Keywords: prebiotics, infant formula, growth, allergy, infections, supplementation

\section{Introduction}

Prebiotics are defined as non-digestible food ingredients that affect the host by selectively targeting growth and/or the activity of one or more bacteria in the colon that can improve health. ${ }^{1}$ Breast-fed infants have an intestinal microbiota dominated by Bifidobacterium and Lactobacilus and this is quite different from the intestinal microbiota of those fed with a standard infant formula. ${ }^{2,3}$ Human milk contains substantial quantities of prebiotics, oligosaccharides which undigested reach the colon and selectively serve as an energy source for desired bacteria, dominantly bifidobacteria. ${ }^{4}$

Intestinal microbiota have been considered an important physiological factor for different functions of the gut; most importantly, development of the immune system. ${ }^{5}$ In recent years, attempts have been made to make intestinal microbiota in formula-fed infants similar to those found in breast-fed infants, mostly by adding pro- and prebiotics. Human milk oligosaccharides are structurally very complex, have a huge diversity and currently are not available for commercial use. ${ }^{4}$ However, several prebiotics have been developed that have a positive effect on the colonization, growth, survival and function of commensal bacteria. Most commonly used prebiotics in infant formulas 
are a mixture of long-chain galacto-oligosaccharides (GOS) and long-chain fructo-oligosaccharides (FOS), both neutral oligosaccharides with proven prebiotic effect. ${ }^{6}$

This review aimed to present available data on the role of prebiotics in infant formula on growth, infection rate and allergies, and on their influence on intestinal microbiota through the bifidogenic and lactogenic effect.

With that aim we performed a literature search which included The Cochrane CENTRAL, EMBASE, Scopus, PubMed/Medline, Web of Science, and Science Direct over the last 10 years (the period from December 2003 to December 2013). All relevant randomized controlled trials (RCT) were included. No other reports - including case series, retrospective trials, crossover trials and uncontrolled trials - were taken into consideration. We included only the studies which were performed on healthy term infants.

\section{Results}

\section{Trial characteristics}

The most commonly studied prebiotic was a 9:1 mixture of GOS and FOS, following with GOS, acidic oligosaccharides (AOS), combination of GOS, FOS and AOS, polydextrose (PDX) and GOS, PDX/GOS and lactulose (LOS), oligofructose and inulin. The prebiotic concentration ranged from 0.12 to $0.8 \mathrm{~g} / 100 \mathrm{~mL}$. Sample size of included studies varied from 20 to 1,130 infants and duration of intervention from 15 days to 6 months.

\section{Stool colonization with bifidobacteria (bifidogenic effect)}

Twelve of the 24 included studies evaluated the effect of prebiotic supplementation on the bifidobacteria in the stools (Table 1). The majority of published studies ${ }^{7-14}$ demonstrated significantly higher levels of bifidobacteria after supplementation, while two trials ${ }^{15,16}$ reported a higher count of bifidobacteria; however this was not statistically significant. Salvini et a ${ }^{17}$ in their small explorative study (sample size 20) reported a long-lasting bifidogenic effect, which continued even 6 months after intervention was stopped. One study looked at the difference in the stool colonies of bifidobacteria in infants fed on prebiotic-supplemented formula and breast-fed infants and found that formula supplemented

Table I Prebiotic-supplemented infant formula and bifidogenic effect

\begin{tabular}{|c|c|c|c|c|c|}
\hline Author & N/age & $\begin{array}{l}\text { Duration } \\
\text { of intervention }\end{array}$ & Setting & Prebiotic & Effect \\
\hline $\begin{array}{l}\text { Bakker-Zierikzee } \\
\text { et al } 2005^{15}\end{array}$ & 34/at birth & 4 months & Healthy term infants & GOS/FOS $0.6 \mathrm{~g} / 100 \mathrm{~mL}$ & $\begin{array}{l}\text { Trend toward higher } \\
\text { counts in prebiotic group }\end{array}$ \\
\hline $\begin{array}{l}\text { Costalos et al } \\
2008^{16}\end{array}$ & $\mid 60 /<14$ days & 15 days & $\begin{array}{l}\text { Healthy term infants, } \\
\text { enrolled } \leq \text { I } 4 \text { days }\end{array}$ & GOS/FOS $0.4 \mathrm{~g} / 100 \mathrm{~mL}$ & $\begin{array}{l}\text { Trend toward higher } \\
\text { counts in prebiotic group }\end{array}$ \\
\hline Decsi et al $2005^{10}$ & 69/at birth & 12 weeks & Healthy term infants & GOS/FOS $0.4 \mathrm{~g} / 100 \mathrm{~mL}$ & Increased in prebiotic group \\
\hline $\begin{array}{l}\text { Fanaro et al } \\
2005^{\prime \prime}\end{array}$ & 3 I/at birth & 6 weeks & Healthy term infants & $\begin{array}{l}\text { I. GOS/FOS } 0.6 \mathrm{~g}+ \\
\text { AOS } 0.2 \mathrm{~g} / 100 \mathrm{~mL} \\
\text { 2. AOS } 0.2 \mathrm{~g} / 100 \mathrm{~mL}\end{array}$ & Increased in prebiotic group \\
\hline $\begin{array}{l}\text { Fanaro et al } \\
2009^{13}\end{array}$ & 159/4-6 months & 12 weeks & Healthy infants & GOS $0.5 \mathrm{~g} / 100 \mathrm{~mL}$ & Increased in prebiotic group \\
\hline $\begin{array}{l}\text { Moro et al } \\
2003^{6}\end{array}$ & 90/at birth & 4 weeks & Healthy term infants & $\begin{array}{l}\text { GOS/FOS } 0.4 \text { and } \\
0.8 \mathrm{~g} / 100 \mathrm{~mL}\end{array}$ & Increased in prebiotic group \\
\hline $\begin{array}{l}\text { Moro et al } \\
2006^{12}\end{array}$ & 206/at birth & 6 months & $\begin{array}{l}\text { Term infants at high } \\
\text { risk for atopy }\end{array}$ & GOS/FOS $0.8 \mathrm{~g} / 100 \mathrm{~mL}$ & Increased in prebiotic group \\
\hline Ben et al $2004^{8}$ & 147/at birth & 6 months & Healthy term infants & GOS $0.24 \mathrm{~g} / 100 \mathrm{~mL}$ & Increased in prebiotic group \\
\hline $\begin{array}{l}\text { Ben et al } \\
2008^{9}\end{array}$ & I64/at birth & 3 months & $\begin{array}{l}\text { Term infants; formula } \\
\text { feeding within } 4 \text { weeks } \\
\text { after birth }\end{array}$ & GOS $0.24 \mathrm{~g} / 100 \mathrm{~mL}$ & Increased in prebiotic group \\
\hline $\begin{array}{l}\text { Salvini et al } \\
2011^{17}\end{array}$ & 20/at birth & 6 months & $\begin{array}{l}\text { Healthy term infants of } \\
\text { HCV-positive mothers }\end{array}$ & GOS/FOS $0.8 \mathrm{~g} / 100 \mathrm{~mL}$ & $\begin{array}{l}\text { Long-lasting bifidogenic } \\
\text { effect }\end{array}$ \\
\hline $\begin{array}{l}\text { Scalabrin } \\
\text { et al } 2012^{14}\end{array}$ & $230 / 21-30$ days & 60 days & Healthy term infants & GOS + PDX $0.4 \mathrm{~g} / 100 \mathrm{~mL}$ & Increased in prebiotic group \\
\hline $\begin{array}{l}\text { Veerman-Wauters } \\
\text { et al } 201 \mathrm{I}^{18}\end{array}$ & $\mid 10 /<5$ days & 28 days & Healthy term infants & $\begin{array}{l}\text { SYNI } 0.4 \mathrm{~g} / 100 \mathrm{~mL} \\
\text { SYNI } 0.8 \mathrm{~g} / 100 \mathrm{~mL} \\
\text { GOS/FOS } 0.8 \mathrm{~g} / 100 \mathrm{~mL}\end{array}$ & $\begin{array}{l}\text { SYNI } 0.8 \text { and GOS/FOS - } \\
\text { comparable to breast-fed } \\
\text { infants }\end{array}$ \\
\hline
\end{tabular}

Abbreviations: GOS, short-chain galacto-oligosaccharides; FOS, long-chain fructo-oligosaccharides; HCV, hepatitis C virus; PDX, polydextrose; AOS, acidic oligosaccharides; SYNI, Synergyl (consists of 50:50 oligofructose and long-chain inulin). 
Table 2 Prebiotic-supplemented infant formula and lactogenic effect

\begin{tabular}{|c|c|c|c|c|c|}
\hline Author & N/age & $\begin{array}{l}\text { Duration of } \\
\text { intervention }\end{array}$ & Setting & Prebiotic & Effect \\
\hline $\begin{array}{l}\text { Fanaro } \\
\text { et al } 2005^{\prime \prime}\end{array}$ & 3 I/at birth & 6 weeks & Healthy term infants & $\begin{array}{l}\text { I. GOS/FOS } 0.6 \mathrm{~g}+ \\
\text { AOS } 0.2 \mathrm{~g} / 100 \mathrm{~mL} \\
\text { 2. AOS } 0.2 \mathrm{~g} / 100 \mathrm{~mL}\end{array}$ & Increased in prebiotic group \\
\hline $\begin{array}{l}\text { Moro } \\
\text { et al } 2006^{12}\end{array}$ & 206/at birth & 6 months & $\begin{array}{l}\text { Term infants at high risk } \\
\text { for atopy }\end{array}$ & GOS/FOS $0.8 \mathrm{~g} / 100 \mathrm{~mL}$ & NS \\
\hline $\begin{array}{l}\text { Ben } \\
\text { et al } 2008^{9}\end{array}$ & 164/at birth & 3 months & $\begin{array}{l}\text { Term infants; formula feeding } \\
\text { within } 4 \text { weeks after birth }\end{array}$ & GOS $0.24 \mathrm{~g} / 100 \mathrm{~mL}$ & Increased in prebiotic group \\
\hline $\begin{array}{l}\text { Salvini } \\
\text { et al } 201 \mathrm{I}^{17}\end{array}$ & 20/at birth & 6 months & $\begin{array}{l}\text { Healthy term infants of } \\
\text { HCV-positive mothers }\end{array}$ & GOS/FOS $0.8 \mathrm{~g} / 100 \mathrm{~mL}$ & Long-lasting lactogenic effect \\
\hline
\end{tabular}

Abbreviations: GOS, short-chain galacto-oligosaccharides; FOS, long-chain fructo-oligosaccharides; AOS, acidic oligosaccharides; NS, not significant; HCV, hepatitis C virus.

with prebiotics has a bifidogenic effect comparable to that of breast milk. ${ }^{18}$

\section{Stool colonization with lactobacilli (lactogenic effect)}

As for the lactogenic effect, we identified only four studies that evaluated the prebiotic effect on the counts of lactobacilli colonies (Table 2). All studies presented the data as actual colony counts per gram of stool. Three studies ${ }^{6,9,18}$ reported higher levels of lactobacilli in the stool after prebiotic supplementation; in contrast, Moro et a ${ }^{12}$ found no difference in colony counts. None of those studies included breast-fed infants.

\section{Growth}

Overall 14 studies measured growth as an outcome (Table 3 ). Growth was validated by body weight, length, and head circumference. In six of the studies, ${ }^{7-10,19,20}$ in addition to the prebiotic and control groups, a group of breast-fed infants was included. All identified trials reported no difference in growth among the groups.

Table 3 Prebiotic-supplemented infant formula and growth

\begin{tabular}{|c|c|c|c|c|c|}
\hline Author & N/age & $\begin{array}{l}\text { Duration of } \\
\text { intervention }\end{array}$ & Setting & Prebiotic & Effect \\
\hline Moro et al $2003^{6}$ & 90/at birth & 4 weeks & Healthy term infants & GOS/FOS 0.4 and $0.8 \mathrm{~g} / 100 \mathrm{~mL}$ & NS \\
\hline Moro et al $2006^{12}$ & 206/at birth & 6 months & $\begin{array}{l}\text { Term infants at high } \\
\text { risk for atopy }\end{array}$ & GOS/FOS $0.8 \mathrm{~g} / 100 \mathrm{~mL}$ & NS \\
\hline Ben et al $2004^{8}$ & |47/at birth & 6 months & Healthy term infants & GOS $0.24 \mathrm{~g} / 100 \mathrm{~mL}$ & NS \\
\hline Ben et al $2008^{9}$ & 164/at birth & 3 months & $\begin{array}{l}\text { Term infants; formula feeding } \\
\text { within } 4 \text { weeks after birth }\end{array}$ & GOS $0.24 \mathrm{~g} / 100 \mathrm{~mL}$ & NS \\
\hline Costalos et al $2008^{16}$ & $160 /<14$ days & 15 days & $\begin{array}{l}\text { Healthy term infants, } \\
\text { enrolled } \leq \text { I } 4 \text { days }\end{array}$ & GOS/FOS $0.4 \mathrm{~g} / 100 \mathrm{~mL}$ & NS \\
\hline Fanaro et al $2005^{\prime \prime}$ & 3 I/at birth & 6 weeks & Healthy term infants & $\begin{array}{l}\text { I. GOS/FOS } 0.6 \mathrm{~g}+ \\
\text { AOS } 0.2 \mathrm{~g} / 100 \mathrm{~mL} \\
\text { 2. AOS } 0.2 \mathrm{~g} / 100 \mathrm{~mL}\end{array}$ & NS \\
\hline Ziegler et al $2007^{28}$ & $226 /<14$ days & 120 days & Healthy term infants & $\begin{array}{l}\text { I. } \mathrm{PDX}+\mathrm{GOS} 0.4 \mathrm{~g} / 100 \mathrm{~mL} \\
\text { 2. } \mathrm{PDX}+\mathrm{GOS}+ \\
\text { LOS } 0.8 \mathrm{~g} / 100 \mathrm{~mL}\end{array}$ & NS \\
\hline Bettler et al $2006^{29}$ & 297/at birth & 12 weeks & Healthy term infants & FOS 0.3 and $0.15 \mathrm{~g} / 100 \mathrm{~mL}$ & NS \\
\hline Decsi et al $2005^{10}$ & 69/at birth & 12 weeks & Healthy term infants & GOS/FOS $0.4 \mathrm{~g} / 100 \mathrm{~mL}$ & NS \\
\hline Alliet et al $2007^{7}$ & 225/at birth & 6 months & Healthy term infants & GOS/FOS $0.6 \mathrm{~g} / 100 \mathrm{~mL}$ & NS \\
\hline $\begin{array}{l}\text { Piemontese } \\
\text { et al } 201 \mathrm{I}^{20}\end{array}$ & $830 /<8$ weeks & I year & Healthy term infants & $\begin{array}{l}\text { GOS/FOS } 0.68 \mathrm{~g} / 100 \mathrm{~mL}+ \\
\text { AOS } 0.12 \mathrm{~g} / 100 \mathrm{~mL}\end{array}$ & NS \\
\hline Brunser et al $2006^{19}$ & $91 / 3.5$ months old & 13 weeks & Healthy term infants & FOS $0.2 \mathrm{~g} / 100 \mathrm{~mL}$ & NS \\
\hline Ribeiro et al $2012^{30}$ & I33/9-48 months & 108 days & Healthy term infants & PDX/GOS $0.5 \mathrm{~g} / 100 \mathrm{~mL}$ & NS \\
\hline Ashley et al $2012^{31}$ & $419 / 12-16$ days & 120 days & Healthy term infants & $\begin{array}{l}\text { I. PDX/GOS } 0.4 \mathrm{~g} / 100 \mathrm{~mL} \\
\text { 2. GOS } 0.4 \mathrm{~g} / 100 \mathrm{~mL}\end{array}$ & NS \\
\hline
\end{tabular}

Abbreviations: GOS, short-chain galacto-oligosaccharides; FOS, long-chain fructo-oligosaccharides; PDX, polydextrose; LOS, lactulose; NS, not significant; AOS, acidic oligosaccharides. 
Table 4 Prebiotic-supplemented infant formula and atopic dermatitis

\begin{tabular}{|c|c|c|c|c|c|}
\hline Author & N/age & $\begin{array}{l}\text { Duration of } \\
\text { intervention }\end{array}$ & Setting & Prebiotic & Effect \\
\hline $\begin{array}{l}\text { Moro } \\
\text { et al } 2006^{12}\end{array}$ & 206/at birth & 6 months & $\begin{array}{l}\text { Term infants at } \\
\text { high risk for atopy }\end{array}$ & $\begin{array}{l}\text { Extensively hydrolyzed whey } \\
\text { formula + GOS/FOS } 0.8 \mathrm{~g} / 100 \mathrm{~mL}\end{array}$ & $\downarrow A D$ \\
\hline $\begin{array}{l}\text { Ziegler } \\
\text { et al } 2007^{28}\end{array}$ & $226 /<14$ days & 120 days & $\begin{array}{l}\text { Healthy term } \\
\text { infants }\end{array}$ & $\begin{array}{l}\text { 1. } P D X+G O S 0.4 \mathrm{~g} / 100 \mathrm{~mL} \\
\text { 2. } P D X+G O S+L O S 0.8 \mathrm{~g} / 100 \mathrm{~mL}\end{array}$ & NS \\
\hline $\begin{array}{l}\text { Arslanoglu } \\
\text { et al } 2008^{22}\end{array}$ & $259 /<6$ months & 6 months & $\begin{array}{l}\text { Term infants at } \\
\text { high risk for atopy }\end{array}$ & $\begin{array}{l}\text { Extensively hydrolyzed whey } \\
\text { formula + GOS/FOS } 0.8 \mathrm{~g} / 100 \mathrm{~mL}\end{array}$ & $\begin{array}{l}2 \text { years follow-up } \\
\text { ( } 134 \text { children finished } \\
\text { follow-up) } \\
\downarrow \text { AD } \\
5 \text { years follow-up } \\
\text { ( } 92 \text { children finished } \\
\text { follow-up): NS AD }\end{array}$ \\
\hline $\begin{array}{l}\text { Gruber } \\
\text { et al } 2010^{21}\end{array}$ & $\mathrm{I}, \mid 30 /<8$ weeks & I year & $\begin{array}{l}\text { Healthy term } \\
\text { infants }\end{array}$ & $\begin{array}{l}\text { Regular formula + GOS/FOS } 0.68 \mathrm{~g} \\
+ \text { AOS } 0.12 \mathrm{~g} / 100 \mathrm{~mL}\end{array}$ & $\downarrow \mathrm{AD}$ \\
\hline
\end{tabular}

Abbreviations: AD, atopic dermatitis; GOS, short-chain galacto-oligosaccharides; FOS, long-chain fructo-oligosaccharides; PDX, polydextrose; LOS, lactulose; AOS, acidic oligosaccharides; NS, not significant.

\section{Allergy}

Results are summarized in the Table 4 . Two studies ${ }^{12,21}$ found a positive effect on the reduction of the risk for atopic dermatitis; however the children included in one study were infants with high risk of atopy ${ }^{12}$ and in the other study, only healthy full-term infants were included. ${ }^{21}$ Arslanoglu et al ${ }^{22}$ showed a protective effect of prebiotic supplementation on allergies in a follow-up period of 2 years; however, that effect was not seen after 5 years of follow-up. ${ }^{23}$ Moreover, both studies had a high dropout rate which should be taken into consideration when interpreting the results.

\section{Respiratory and gastrointestinal infections}

Results of the trials investigating the role of prebiotics on infection prevention are summarized in Tables 5 and 6 .
Arslanoglu et $\mathrm{al}^{24}$ reported fewer episodes of physician-diagnosed overall and upper respiratory tract infections and fewer antibiotic prescriptions. Bruzzese et $\mathrm{al}^{25}$ reported a lower incidence of gastroenteritis in the supplemented group. On the other hand, the study by van Stuijvenberg et $\mathrm{al}^{26}$ found a non-significant difference in the number of fever episodes.

\section{Discussion}

Currently available data show that prebiotic supplementation of infant formula can yield bifidogenic and lactogenic effects similar to those found in breast-fed babies. That trend was reported by all studies using the prebiotic mixture GOS/FOS. On the other hand, acidic oligosaccharides failed to yield the same effect when used alone, but when used in combination with the GOS/FOS mixture, an effect was observed. ${ }^{11}$ As far as concentration is concerned, both effects have been

Table 5 Prebiotic-supplemented infant formula and respiratory tract infections

\begin{tabular}{|c|c|c|c|c|}
\hline Author & N/age & Setting & Prebiotic & Effect \\
\hline $\begin{array}{l}\text { Arslanoglu } \\
\text { et al } 2007^{24}\end{array}$ & $259 /<6$ months & $\begin{array}{l}\text { Term infants with a } \\
\text { parental history of atopy }\end{array}$ & GOS/FOS $0.8 \mathrm{~g} / 100 \mathrm{~mL}$ & $\begin{array}{l}\text { No significant difference in the } \\
\text { incidence of respiratory tract infections } \\
\text { Lower incidence of recurrent } \\
\text { upper respiratory infections } \\
\text { No difference in prescribed antibiotics }\end{array}$ \\
\hline $\begin{array}{l}\text { Arslanoglu } \\
\text { et al } 2008^{22}\end{array}$ & $259 /<6$ months & $\begin{array}{l}\text { Term infants with a } \\
\text { parental history of atopy }\end{array}$ & GOS/FOS $0.8 \mathrm{~g} / 100 \mathrm{~mL}$ & $\begin{array}{l}\text { Two years follow-up (I } 34 \text { children } \\
\text { finished follow-up): lower number } \\
\text { of upper respiratory tract infections } \\
\text { Lower number of prescribed antibiotics }\end{array}$ \\
\hline $\begin{array}{l}\text { Bruzzese } \\
\text { et al } 2009^{25}\end{array}$ & $342 / 15-120$ days & Healthy term infants & GOS/FOS $0.4 \mathrm{~g} / 100 \mathrm{~mL}$ & No significant difference in the incidence \\
\hline $\begin{array}{l}\text { van Stuijvenberg } \\
\text { et al } 20 \mathrm{II}^{26}\end{array}$ & $830 /<8$ weeks & Healthy term infants & $\begin{array}{l}\text { GOS/FOS } 0.68 \mathrm{~g}+\text { AOS } 0.12 \\
\mathrm{~g} / 100 \mathrm{~mL}\end{array}$ & $\begin{array}{l}\text { No significant difference in the incidence } \\
\text { No difference in prescribed antibiotics }\end{array}$ \\
\hline $\begin{array}{l}\text { Ribeiro } \\
\text { et al } 2012^{30}\end{array}$ & 133/9-48 months & Healthy term infants & PDX/GOS $0.5 \mathrm{~g} / 100 \mathrm{~mL}$ & $\begin{array}{l}\text { No significant difference in the incidence } \\
\text { Lower number of prescribed antibiotics }\end{array}$ \\
\hline
\end{tabular}

Abbreviations: GOS, short-chain galacto-oligosaccharides; FOS, long-chain fructo-oligosaccharides; PDX, polydextrose; AOS, acidic oligosaccharides. 
Table 6 Prebiotic-supplemented formula and gastrointestinal infection

\begin{tabular}{|c|c|c|c|c|c|}
\hline Author & N/age & $\begin{array}{l}\text { Duration of } \\
\text { intervention } \\
\text { or follow-up }\end{array}$ & Setting & Prebiotic & Effect \\
\hline $\begin{array}{l}\text { Arslanoglu } \\
\text { et al } 2007^{24}\end{array}$ & $259 /<6$ months & 6 months & $\begin{array}{l}\text { Term infants with a } \\
\text { parental history of atopy }\end{array}$ & GOS/FOS $0.8 \mathrm{~g} / 100 \mathrm{~mL}$ & NS \\
\hline $\begin{array}{l}\text { Arslanoglu } \\
\text { et al } 2008^{22}\end{array}$ & $259 /<6$ months & 6 months & $\begin{array}{l}\text { Term infants with a } \\
\text { parental history of atopy }\end{array}$ & GOS/FOS $0.8 \mathrm{~g} / 100 \mathrm{~mL}$ & $\begin{array}{l}2 \text { years follow-up (1 } 34 \text { children } \\
\text { finished follow-up): NS }\end{array}$ \\
\hline $\begin{array}{l}\text { Ribeiro } \\
\text { et al } 2012^{30}\end{array}$ & I33/9-48 months & 108 days & Healthy term infants & PDX/GOS $0.5 \mathrm{~g} / 100 \mathrm{~mL}$ & NS \\
\hline $\begin{array}{l}\text { Bruzzesse } \\
\text { et al } 2009^{25}\end{array}$ & $342 / 15-120$ days & I year & Healthy term infants & GOS/FOS $0.4 \mathrm{~g} / 100 \mathrm{~mL}$ & $\begin{array}{l}\text { Lower number of } \\
\text { gastrointestinal infections }\end{array}$ \\
\hline $\begin{array}{l}\text { van Stuijvenberg } \\
\text { et al } 201 \mathrm{I}^{26}\end{array}$ & $830 /<8$ weeks & I year & Healthy term infants & $\begin{array}{l}\text { GOS/FOS } 0.68 \mathrm{~g}+ \\
\text { AOS } 0.12 \mathrm{~g} / 100 \mathrm{~mL}\end{array}$ & NS \\
\hline
\end{tabular}

Abbreviations: GOS, short-chain galacto-oligosaccharides; FOS, long-chain fructo-oligosaccharides; PDX, polydextrose; AOS, acidic oligosaccharides; NS, not significant.

achieved with the concentration recommended by the Scientific Committee on Food of the European Commission (ie, lower than $8 \mathrm{~g} / 100 \mathrm{~mL}$ of milk). ${ }^{27}$

However, although presented studies proved that prebiotics have a bifidogenic and lactogenic effect, their clinical relevance still remains unknown. Moreover, we are not aware whether or not that effect on intestinal microbiota early in life could be long-lasting or whether it could also have clinical relevance later in life. Currently available data assessed only short-term clinical effects including growth, allergy and infection rate. As far as growth was concerned, none of the studies showed a significant difference between the supplemented and non-supplemented group. ${ }^{6-12,16,19,20,28-31}$ However, several limitations should be considered: first of all, the role model for ideal infant growth is not the formula-fed but the breast-fed infant; moreover, none of those studies assessed long-term prebiotic effect on infant growth.

There is some evidence that a prebiotic supplementation may prevent eczema. ${ }^{12,21}$ However, the evidence is weak; moreover, studies which measured long-lasting effect had very high dropout during the follow-up. ${ }^{22,23}$ It is still unclear whether the use of prebiotics should be restricted only to infants at high risk of allergy or whether they should also be used in low-risk populations. For the evidence-based recommendation on the use of prebiotics in infant formula for allergy prevention, we need more well-performed randomized controlled trials with long-term follow-up.

The role of prebiotics in the prevention of respiratory and gastrointestinal infections is still controversial; the number of well-designed clinical trials is limited. Regarding the effect on upper respiratory tract infections, the data is not unequivocal; there are two studies both on the same cohort, one during the use of prebiotics and the other during the follow-up. ${ }^{22,24}$ Both studies found a decreased incidence of respiratory tract infections. However, the follow-up study had a very high drop-out rate and, furthermore, intention-to-treat analysis was not performed. ${ }^{22}$ In these two studies the significant difference in the number of gastrointestinal infections was not observed. Because there is no clear evidence, further recommendation of the role of prebiotics in the prevention of infections could not be given.

The European Society of Paediatric Gastroenterology, Hepatology and Nutrition (ESPGHAN) Committee on Nutrition published a Position Paper in 2011 on the role of supplementation of infant formula with pro- and prebiotics in different clinical outcomes. ${ }^{32}$ The overall recommendation of that systematic review was that there was not enough evidence to recommend routine supplementation of infant formula with pro- and prebiotics. However, it was also clearly stated that supplementation does not raise safety concerns regarding side effects and infants' growth.

\section{Conclusion}

Currently available evidence failed to find positive effect of prebiotics in infant formula on growth and any other studied clinical outcome in healthy term infants. It has been found that prebiotics, during administration, can modify intestinal microbiota; however, clinical relevance still remains questionable. Certainly, well-designed, prospective, longterm studies are needed in order to provide the best possible alternative for infants who cannot be breast-fed.

\section{Disclosure}

The authors report no conflicts of interest in this work.

\section{References}

1. Gibson GR, Roberfroid MB. Dietary modulation of the human colonic microbiota: introducing the concept of prebiotics. $J$ Nutr. 1995;125: 1401-1412. 
2. Harmsen HJ, Wildeboer-Veloo AC, Raangs GC, et al. Analysis of intestinal flora development in breast-fed and formula-fed infants by using molecular identification and detection methods. J Pediatr Gastroenterol Nutr. 2000;30:61-67.

3. Rubaltelli FF, Biadaioli R, Pecile P, Nicoletti P. Intestinal flora in breast- and bottle-fed infants. J Perinat Med. 1998;26:186-191.

4. Bode L. Human milk oligosaccharides: prebiotics and beyond. Nutr Rev. 2009;67 Suppl 2:S183-S191.

5. Heavey PM, Rowland IR. Microbial-gut interactions in health and disease. Gastrointestinal cancer. Best Pract Res Clin Gastroenterol. 2004; 18:323-336.

6. Moro GE, Mosca F, Miniello V, et al. Effects of a new mixture of prebiotics on faecal flora and stools in term infants. Acta Paediatr Suppl. 2003;91:77-79.

7. Alliet P, Scholtens P, Raes M, et al. Effect of prebiotic galactooligosaccharide, long-chain fructo-oligosaccharide infant formula on serum cholesterol and triacylglycerol levels. Nutrition. 2007;23: 719-723.

8. Ben XM, Zhou XY, Zhao WH, et al. Supplementation of milk formula with galacto-oligosaccharides improves intestinal micro-flora and fermentation in term infants. Chin Med J (Engl). 2004;117: 927-931.

9. Ben XM, Li J, Feng ZT, et al. Low level of galacto-oligosaccharide in infant formula stimulates growth of intestinal Bifidobacteria and Lactobacilli. World J Gastroenterol. 2008;14:6564-6568.

10. Decsi T, Arato A, Balogh M, et al. [Randomised placebo controlled double blind study on the effect of prebiotic oligosaccharides on intestinal flora in healthy infants]. Orv Hetil. 2005;146:2445-2450. Hungarian.

11. Fanaro S, Jelinek J, Stahl B, et al. Acidic oligosaccharides from pectin hydrolysate as new component for infant formulae: effect on intestinal flora, stool characteristics, and $\mathrm{pH}$. J Pediatr Gastroenterol Nutr. 2005;41:186-190.

12. Moro G, Arslanoglu S, Stahl B, et al. A mixture of prebiotic oligosaccharides reduces the incidence of atopic dermatitis during the first six months of age. Arch Dis Child. 2006;91:814-819.

13. Fanaro S, Marten B, Bagna R, et al. Galacto-oligosaccharides are bifidogenic and safe at weaning: a double-blind randomized multicenter study. J Pediatr Gastroenterol Nutr. 2009;48:82-88.

14. Scalabrin DM, Mitmesser SH, Welling GW, et al. New prebiotic blend of polydextrose and galacto-oligosaccharides has a bifidogenic effect in young infants. J Pediatr Gastroenterol Nutr. 2012;54:343-352.

15. Bakker-Zierikzee AM, Alles MS, Knol J, Kok FJ, Tolboom JJ, Bindels JG. Effects of infant formula containing a mixture of galactoand fructo-oligosaccharides or viable Bifidobacterium animalis on the intestinal microflora during the first 4 months of life. Br J Nutr. 2005;94: 783-790.

16. Costalos C, Kapiki A, Apostolou M, Papathoma E. The effect of a prebiotic supplemented formula on growth and stool microbiology of term infants. Early Hum Dev. 2008;84:45-49.

17. Salvini F, Riva E, Salvatici E, et al. A specific prebiotic mixture added to starting infant formula has long-lasting bifidogenic effects. J Nutr. 2011;141:1335-1339.
18. Veereman-Wauters G, Staelens S, Van de Broek H, et al. Physiological and bifidogenic effects of prebiotic supplements in infant formulae. J Pediatr Gastroenterol Nutr. 2011;52:763-771.

19. Brunser O, Figueroa G, Gotteland M, et al. Effects of probiotic or prebiotic supplemented milk formulas on fecal microbiota composition of infants. Asia Pac J Clin Nutr. 2006;15:368-376.

20. Piemontese P, Gianni ML, Braegger CP, et al. Tolerance and safety evaluation in a large cohort of healthy infants fed an innovative prebiotic formula: a randomized controlled trial. PLoS One. 2011;6:e28010.

21. Gruber C, van Stuijvenberg M, Mosca F, et al. Reduced occurrence of early atopic dermatitis because of immunoactive prebiotics among low-atopy-risk infants. J Allergy Clin Immunol. 2010;126:791-797.

22. Arslanoglu S, Moro GE, Schmitt J, Tandoi L, Rizzardi S, Boehm G. Early dietary intervention with a mixture of prebiotic oligosaccharides reduces the incidence of allergic manifestations and infections during the first two years of life. J Nutr. 2008;138:1091-1095.

23. Arslanoglu S, Moro GE, Boehm G, Wienz F, Stahl B, Bertino E. Early neutral prebiotic oligosaccharide supplementation reduces the incidence of some allergic manifestations in the first 5 years of life. J Biol Regul Homeost Agents. 2012;26:49-59.

24. Arslanoglu S, Moro GE, Boehm G. Early supplementation of prebiotic oligosaccharides protects formula-fed infants against infections during the first 6 months of life. J Nutr. 2007;137:2420-2424.

25. Bruzzese E, Volpicelli M, Squeglia V, et al. A formula containing galactoand fructo-oligosaccharides prevents intestinal and extra-intestinal infections: an observational study. Clin Nutr. 2009;28:156-161.

26. van Stuijvenberg M, Eisses AM, Gruber C, et al. Do prebiotics reduce the number of fever episodes in healthy children in their first year of life: a randomised controlled trial. Br J Nutr. 2011;106:1740-1748.

27. European Commission. Commission Directive 2006/141/EC of 22 December 2006 on Infant Formulae and Follow-on Formulae and Amending Directive 1999/21/EC. Brussels: European Commission; 2006. Available from: http://eurlex.europa.eu/LexUriServ/LexUriServ. do?uri=OJ:L:2006:401:0001:0033:EN:PDF. Accessed Dec 2013.

28. Ziegler E, Vanderhoof JA, Petschow B, et al. Term infants fed formula supplemented with selected blends of prebiotics grow normally and have soft stools similar to those reported for breast-fed infants. $J$ Pediatr Gastroenterol Nutr. 2007;44:359-364.

29. Bettler J, Euler AR. An evaluation of the growth of term infants fed formula supplemented with fructo-oligosacchairde. Int J Probiotics Prebiotics. 2006;1:19-26.

30. Ribeiro TC, Costa-Ribeiro H Jr, Almeida PS, et al. Stool pattern changes in toddlers consuming a follow-on formula supplemented with polydextrose and galactooligosaccharides. J Pediatr Gastroenterol Nutr. 2012;54:288-290.

31. Ashley C, Johnston WH, Harris CL, Stolz SI, Wampler JL, Berseth CL. Growth and tolerance of infants fed formula supplemented with polydextrose (PDX) and/or galactooligosaccharides (GOS): double-blind, randomized, controlled trial. Nutr J. 2012;11:38.

32. Braegger C, Chmielewska A, Decsi T, et al. Supplementation of infant formula with probiotics and/or prebiotics: a systematic review and comment by the ESPGHAN committee on nutrition. J Pediatr Gastroenterol Nutr. 2011;52:238-250.
Nutrition and Dietary Supplements

\section{Publish your work in this journal}

Nutrition and Dietary Supplements is an international, peer-reviewed, open access journal focusing on research into nutritional requirements in health and disease, impact on metabolism and the identification and optimal use of dietary strategies and supplements necessary for normal growth and development. The journal welcomes papers covering

Submit your manuscript here: http://www.dovepress.com/nutrition-and-dietary-supplements-journal

\section{Dovepress}

original research, basic science, clinical \& epidemiological studies, reviews and evaluations, guidelines, expert opinion and commentary, case reports and extended reports. The manuscript management system is completely online and includes a very quick and fair peer-review system, which is all easy to use. 